\title{
Kinetic and Fixed Bed Studies for Copper Removal from Solutions by Walnut Tree Sawdust (Juglans regia Linnaeus)
}

\author{
Çakir E. ${ }^{1}$, Tosunoğlu V. ${ }^{1}$, Boncukcuoğlu R. ${ }^{2}$, Korkmaz M. ${ }^{3}$ and Fil B.A. ${ }^{3,}$ \\ ${ }^{1}$ Atatürk University, Engineering Faculty, Department of Environmental Engineering, 25240, Erzurum, Turkey \\ ${ }^{2}$ Istanbul University, Engineering Faculty, Department of Environmental Engineering, 34320, Istanbul, Turkey \\ ${ }^{3}$ Balikesir University, Engineering Faculty, Department of Environmental Engineering, 10145, Balikesir, Turkey \\ Received: 26/09/2016, Accepted: 04/02/2017, Available online: 05/10/2017 \\ *to whom all correspondence should be addressed: e-mail: baybarsalifil2@gmail.com
}

\begin{abstract}
This study investigates the adsorption kinetics and removal conditions of copper by walnut tree sawdust from synthetic solutions in the batch and fixed bed reactors. The selected experimental parameters for the batch reactor were concentration, solution $\mathrm{pH}$, adsorbent amount and temperature. The optimum batch reactor conditions were applied to the fixed bed reactor. The experimental parameters of the fixed bed reactor were flow rate, bed height, and concentration. The optimum removal conditions for copper removal in the batch reactor were determined as $\mathrm{pH}(5)$, temperature $\left(25^{\circ} \mathrm{C}\right)$, concentration $(25 \mathrm{mg} / \mathrm{L})$, and adsorbent dosage $(10 \mathrm{~g} / \mathrm{L})$. The kinetic data obtained from the batch reactor were analyzed by the pseudo-first-order and the pseudo-second-order kinetic models and the kinetic data were successfully correlated with the pseudo-second-order model. Activation energy of the process was calculated to be $15.79 \mathrm{~kJ} / \mathrm{mol}$. The optimum parameters for the fixed bed reactor were designated as $0.5 \mathrm{~mL} / \mathrm{min}$ flow rate, $100 \mathrm{mg} / \mathrm{L}$ concentration and $15 \mathrm{~cm}$ bed height. The kinetic data obtained from the fixed bed reactor were analyzed with the Yoon-Nelson and Thomas kinetic models. The fixed bed kinetics could be described with the Thomas model. Maximum adsorption capacity was calculated as $6.24 \mathrm{mg} / \mathrm{g}$ in the fixed bed reactor.
\end{abstract}

Keywords: Walnut sawdust, Copper removal, Kinetics, Batch reactor, Fixed bed reactor

\section{Introduction}

Heavy metals in the surface waters cause a big anxiety in the World because these metal ions accumulate in the living creatures. Heavy metals are un-biodegradable by the microorganisms in the biological treatment systems (Korkmaz et al., 2013). Therefore, physico-chemical methods have been developed by the scientists to reduce the metal concentration to confident level. The industries such as electroplating, metal finishing, metallurgy, tanning, chemical manufacturing, mining and battery manufacturing take part at the head of the main reasons of heavy metal pollution in the surface waters (Lu and Gibb,
2008). Wind-blown dust, volcanic emissions, decaying vegetation, forest fires and sea spray are among the natural reasons of the copper presence in the environment (Vilar et al., 2008). Agricultural use of copper containing fertilizers or remedies is responsible for $2 \%$ of soil copper content (Vilar et al., 2008). The copper in the soil forms insoluble organic copper complexes with humic and fulvic acids and this makes difficult the washing of copper from the polluted soils by rains (Korkmaz et al., 2013). Therefore, copper accumulation in the soil increases and this creates a big potential for copper deposition in plants. Copper limit value for drinking water and wastewaters discharge is proposed as $1.3 \mathrm{mg} / \mathrm{L}$ (Fil et al., 2014). Copper deficiency in humans results with anemia, neutropenia and bone abnormalities, but clinically determined number of patients affected from copper deficiency is relatively low (Vilar et al., 2008). The short term exposure of humans to copper above $1.3 \mathrm{mg} / \mathrm{L}$ results with stomach and intestinal problems; however, long-term exposure to copper causes to kidney and liver damage, and DNA mutation (Cojocaru and Zakrzewska-Trznadel, 2007). Copper is a required element for humans and daily needed copper amount is estimated to be $2 \mathrm{mg}$ ( $\mathrm{Lu}$ and Gibb, 2008). Therefore, to prevent the contamination of surface water sources with copper, the wastewaters containing-copper are to be treated before being discharged.

The treatment requirement for heavy metals has led to improvement of advanced physico-chemical methods. Several methods for copper removal from wastewaters have been proposed and these are flotation (Ghazy et al., 2006; Luo and Huang, 1993), adsorption (Korkmaz et al., 2013; Juang et al., 1999), ion exchange (Veli and Pekey, 2004; Cerjan-Stefanovic et al., 1996), electrodialysis (Caprarescu et al., 2014; Öğütveren et al., 1997), solvent extraction (Kitobo et al., 2010; Sole and Hiskey, 1995), and membrane filtration (Malamis et al., 2010; Juang and Chen, 1997). Biosorbents are naturally abundant materials and by-products arising from some industries or agricultural production (Lu and Gibb, 2008). Biosorption can be shown as alternative to the mentioned technologies which are of some drawbacks such as high operation cost and generation of solid wastes needing disposal (Preetha and 
Viruthagiri, 2007). In this study, walnut tree sawdust was used as an adsorbent for copper removal from solutions. According to the average 2000-2005 statistics, Turkish walnut production has accounted for $8.89 \%$ of the World's total walnut production (Akça and Polat, 2007). Therefore, Turkey has a high potential in respect to walnut sawdust production. Bulut and coworker studied the adsorption of nickel ions on the walnut sawdust after modification with $\mathrm{HCHO}$ in sulphuric acid solution and the capacity of the sawdust was reported as $6.43 \mathrm{mg} / \mathrm{g}$ (Bulut and Tez, 2003). In the another study, the adsorption of $\mathrm{Ni}^{2+}, \mathrm{Pb}^{2+}$ and $\mathrm{Cd}^{2+}$ adsorption onto walnut sawdust was studied and it was reported that ion exchange was probably one of the major adsorption mechanisms for binding divalent metal ions to the walnut sawdust (Bulut and Tez, 2007). To the best of our knowledge, there is no study aiming the removal of copper from solutions by walnut tree sawdust in the batch and fixed bed reactors as a function of changing experimental conditions.

It is important to study the adsorption kinetics and equilibrium which give important information for the design of the batch and fixed bed reactors. Equilibrium studies give information about the adsorbate adsorption mechanism on the adsorbent (Khormaei et al., 2007). For instance, while the Freundlich isotherm indicates the physical adsorption, the Langmuir isotherm represents chemical reaction. Batch kinetic studies are generally modeled by the pseudo-first-order, pseudo-second-order, elemental and modified Freundlich kinetic models. The fixed bed reactor provides easy handling of adsorbent material and wastewater. The widely used fixed bed kinetic models are Yoon-Nelson and Thomas models. Therefore, in this study, copper removal from synthetically prepared solutions was studied at batch and fixed bed reactors.

For this purpose, the selected experimental parameters were $\mathrm{pH}$, concentration, temperature, time, adsorbent dosage, solution flow rate, and bed height. The kinetic data obtained from the batch process were applied to pseudofirst-order and pseudo-second-order kinetic model. In addition to this, the kinetic data obtained from the fixed bed process were applied to the Yoon-Nelson and Thomas models.

\section{Materials and Methods}

The working solutions were prepared from the stock copper solution with $1,000 \mathrm{mg} / \mathrm{L}$ concentration. The stock solution was prepared from copper nitrate trihydrate, $\mathrm{Cu}\left(\mathrm{NO}_{3}\right)_{2} \cdot 3 \mathrm{H}_{2} \mathrm{O}$ (Merck Product). The $\mathrm{pH}$ values of solutions were adjusted using $20 \% \mathrm{H}_{2} \mathrm{SO}_{4}$ and $0.5 \mathrm{M} \mathrm{NaOH}$ solutions (Merck Product). The particle size of the used walnut tree sawdust were in the range of 0-0.5 mm. BET surface area, pore size, micropore area, external surface area, Langmuir surface area of the adsorbent were measured as 0.8588 $\mathrm{m}^{2} / \mathrm{g}, 5.95709 \mathrm{~nm}, 0.1582 \mathrm{~m}^{2} / \mathrm{g}, 0.7005 \mathrm{~m}^{2} / \mathrm{g}$ and 1.2434 $\mathrm{m}^{2} / \mathrm{g}$, respectively. In the batch mode studies, the effect of concentration, $\mathrm{pH}$, adsorbent dosage, time and temperature were studied. The solutions were stirred using a magnetic stirrer in the batch studies (Termolyne NUOVA II). Upon to preparation of the working solutions as $100 \mathrm{~mL}$,
$\mathrm{pH}$ values of the solutions were adjusted and the solutions were heated to desired temperature value in a $250 \mathrm{~mL}$ jacketed batch reactor. Then, adsorbent was added to the solution and magnetic stirrer was switched on. After the reaction, the taken solution from the batch reactor was filtered using Schleicher \& Schüll 5893 filter paper. Copper concentrations in the taken solution were measured using UV-160A (SHIMADZU) spectrophotometer. The procedure for copper analysis was reported in another study (Çakır, 2015). The optimum conditions ( $\mathrm{pH}=5$ and temperature $=25^{\circ} \mathrm{C}$ ) obtained from the batch studies were applied to the fixed bed reactor. The applied parameters in the fixed bed reactor were flow rate $(0.5,1.5$ and 2.5 $\mathrm{mL} / \mathrm{min})$, bed height $(3.75,7.5$ and $15 \mathrm{~cm})$, concentration (100, 125, 150 and $175 \mathrm{mg} / \mathrm{L})$ and time. The experimental setup for the batch and fixed bed processes are given in Figure 1.

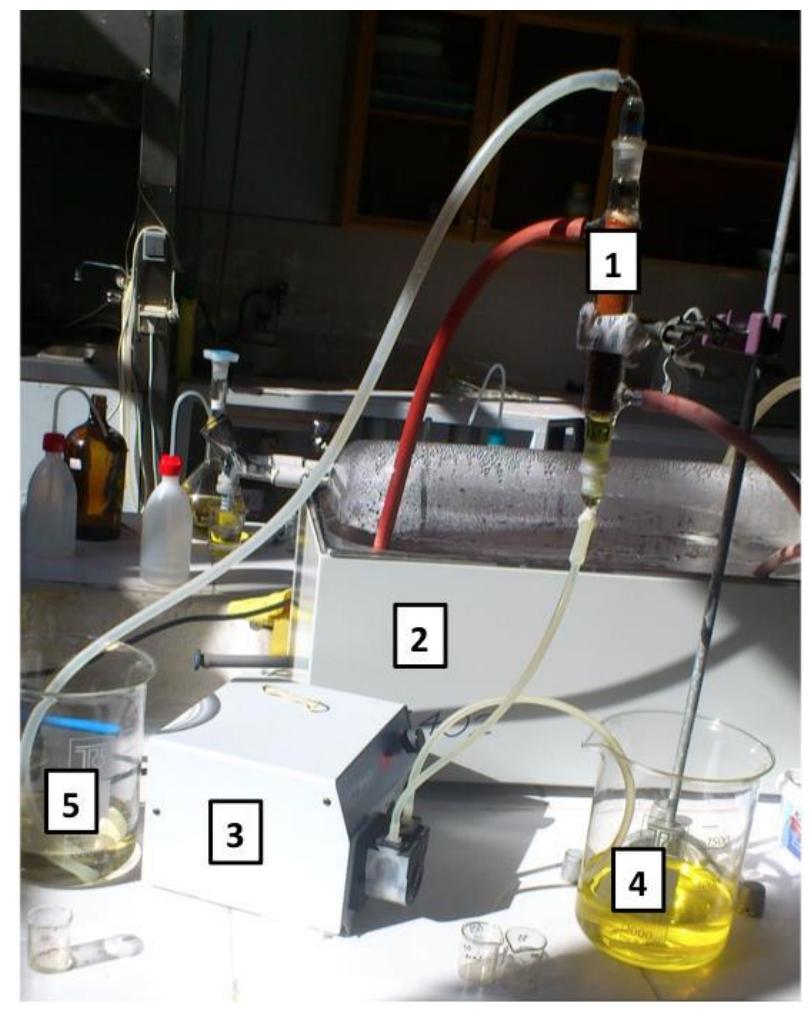

Figure 1. Experimental set up (1- Column, 2-Circulator, 3Perilstaltik pump, 4-Raw wastewater, 5-Treated wastewater)

\section{Results and Discussion}

\section{1. pH Effect on Copper Removal by Walnut Sawdust}

The wastewaters containing heavy metals have changing $\mathrm{pH}$ values based on the industry type and initial solution $\mathrm{pHs}$ of the wastewaters should be arranged before being treated by adsorption. In the applied biosorption process for copper removal by the walnut tree sawdust, initial solution pHs were arranged to 2, 3, 4, and 5 values and other parameters were kept as constant: $75 \mathrm{mg} / / \mathrm{L}$ concentration, $25^{\circ} \mathrm{C}$ temperature, $10 \mathrm{~g} / \mathrm{L}$ solid-to-solution ratio (solution volume was $100 \mathrm{~mL}$ ), $150 \mathrm{rpm}$ stirring speed. The obtained results are given in Figure 2. 


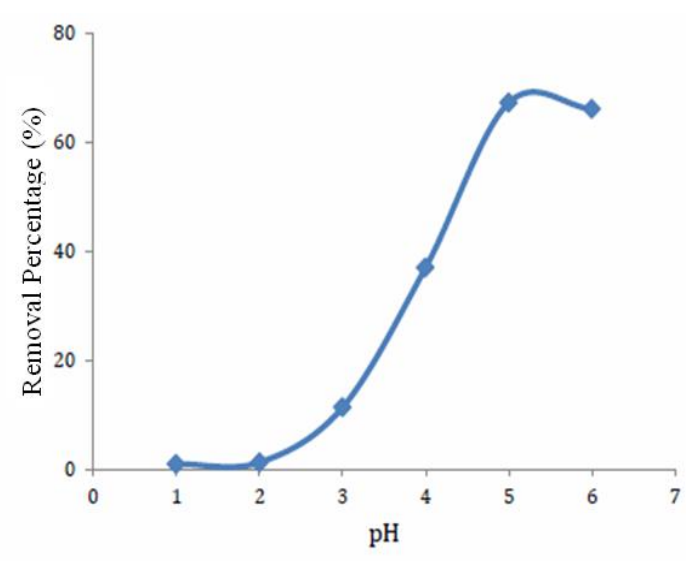

Figure 2. $\mathrm{pH}$ Effect on the adsorption

Copper adsorption onto walnut tree sawdust increased with increasing initial solution $\mathrm{pH}$ and optimum $\mathrm{pH}$ was determined as 5 . Copper concentrations were decreased from $75 \mathrm{mg} / \mathrm{L}$ to $74.09,66.50,47.29$, and $24.63 \mathrm{mg} / \mathrm{L}$ for 2 , 3,4 , and $5 \mathrm{pH}$ values. Maximum copper adsorption capacities for $\mathrm{pH}$ values of $2,3,4$, and 5 were calculated as $0.091,0.85,2.771$ and $5.037 \mathrm{mg} / \mathrm{g}$, respectively. The walnut tree sawdust surface was protonated at low pHs and hydrogen ions exhibited competitive adsorption with copper ions. On the contrary, walnut tree sawdust surface gathered negative charge with $\mathrm{pH}$ increase and much more copper ions adsorbed onto negatively charged surface. The $\mathrm{pH}$ value that should be reached to form metal hydroxide can be given a limit value for $\mathrm{pH}$ adjustment. Copper adsorption onto clinoptilolite (Korkmaz et al., 2013), copper adsorption onto illite clay (Fil et al., 2014), copper adsorption onto waste beer yeast (Han et al., 2006) and copper adsorption onto Spirulina platensis biomass (AlHomaidan et al., 2014) increased with pH increase.

\subsection{Adsorbent amount effect on copper removal by walnut Sawdust}

Adsorbent amount in metal solutions is important to provide optimum adsorbent surface for metal adsorption. The effect of walnut tree sawdust amount on copper removal was studied at 2, 5, 8, $10 \mathrm{~g} / \mathrm{L}$ and other parameters were as follows: $75 \mathrm{mg} / \mathrm{L}$ concentration, temperature $25^{\circ} \mathrm{C}$, $\mathrm{pH} \mathrm{5,} \mathrm{stirring} \mathrm{speed} 150 \mathrm{rpm}$. The experimental results are given in Figure 3.

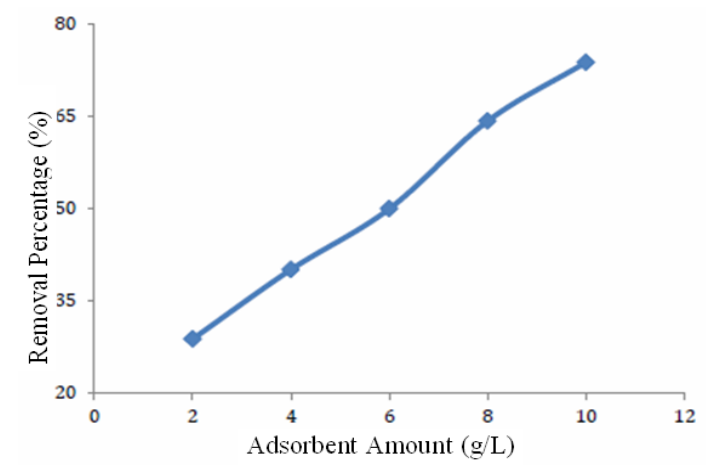

Figure 3. Adsorbent amount effect on the adsorption
As can be seen in Figure 3, copper removal increased with increasing walnut tree sawdust amount. Copper concentrations were decreased from $75 \mathrm{mg} / \mathrm{L}$ to 45.41 , $37.65,24.80,24.29 \mathrm{mg} / \mathrm{L}$ for $2,5,8,10 \mathrm{~g} / \mathrm{L}$ adsorbent amounts. The reason of removal efficiency increase at high adsorbent dosages was increase of effective surface area with adsorbent amount increase. Similar results were obtained for copper removal by Chlorella vulgaris (Al-Rub et al., 2006).

\subsection{Concentration, temperature and time effect on copper removal by Walnut Sawdust}

Adsorption experiments carried out in batch mode as a function of time are the most common way to find out the kinetics of the process and the rate constant is the most important design parameter as it controls the retention time (Chabani et al., 2007; Özmetin et al., 2009). Optimum time for the batch and fixed bed reactors can be determined by conducting kinetic studies. The time above of which removal efficiency does not change can be determined as design time. Concentration is the other parameter affecting performance of batch systems. Concentration gradient enforces the metal ions to diffuse into pores of adsorbents or to adsorb onto adsorbent surface (Korkmaz, 2011). Temperature either increases or decreases the adsorption capacity of the adsorbents because the adsorption mechanism is either endothermic or exothermic. Also, adsorbents can cower with temperature decrease and results in pore diffusion resistance, on the other hand, the adsorbents can swell with temperature increase that causing to decrease of pore diffusion resistance (Fil et al., 2014; Özmetin et al., 2009). In this study, copper removal as a function of time, concentration and temperature is given in Figure 4-7. In the study, while concentrations were changed from 25 to 100 $\mathrm{mg} / \mathrm{L}$, temperatures were changed from 25 to $40^{\circ} \mathrm{C}$. When Figures 4-7 were taken care of, optimum temperature was determined as $25^{\circ} \mathrm{C}$ at $25,50,75$ and $100 \mathrm{mg} / \mathrm{L}$ copper concentrations for a time slice of $60 \mathrm{~min}$. At low concentrations such as $25,50 \mathrm{mg} / \mathrm{L}$, the walnut tree sawdust did not reach the saturation; however, the adsorbent reached to saturation at higher concentrations. From the temperature effect studies, the copper adsorption on walnut tree sawdust was found as exothermic process.

The widely used kinetic models to fit the adsorption data are pseudo-first-order and pseudo-second-order kinetic models. The pseudo first order kinetic model generally fits for the rapid period of the adsorption (Özmetin et al., 2009). Pseudo second order kinetic model generally indicates chemical adsorption nature. Lagergren presented a first-order rate equation to describe the kinetic process of liquid-solid phase adsorption of oxalic acid and malonic acid onto charcoal and the pseudo-first-order kinetic model is given as follows (Lagergren and Svenska, 1898):

$$
\ln \left(q_{e}-q_{t}\right)=-k_{1} \cdot t
$$




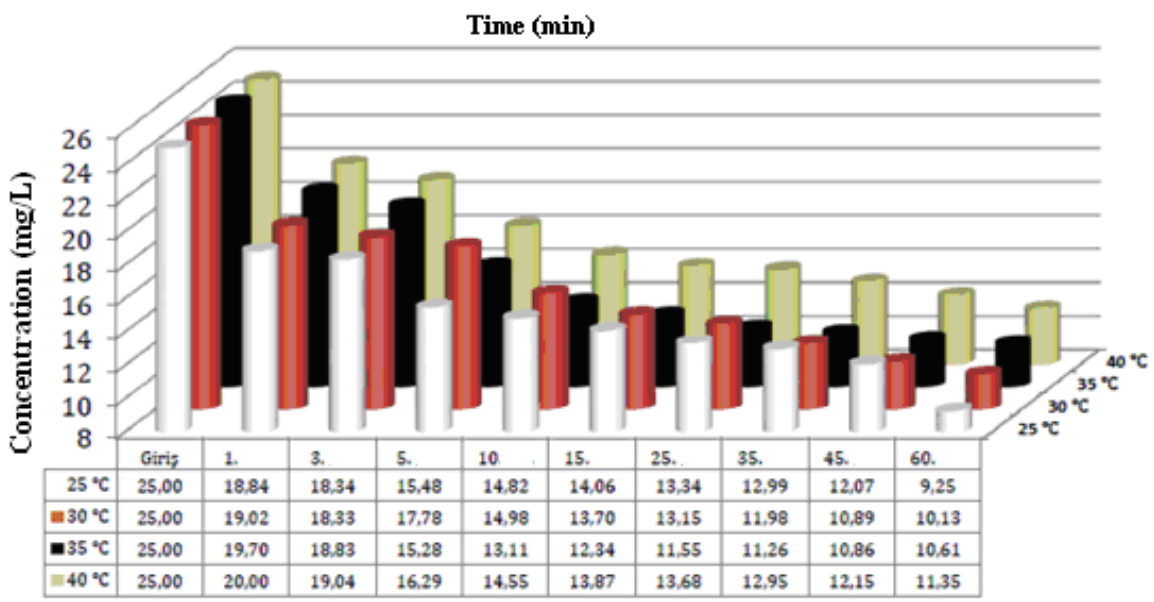

Figure 4. Temperature effect on the adsorption at $25 \mathrm{mg} / \mathrm{L}$ concentration

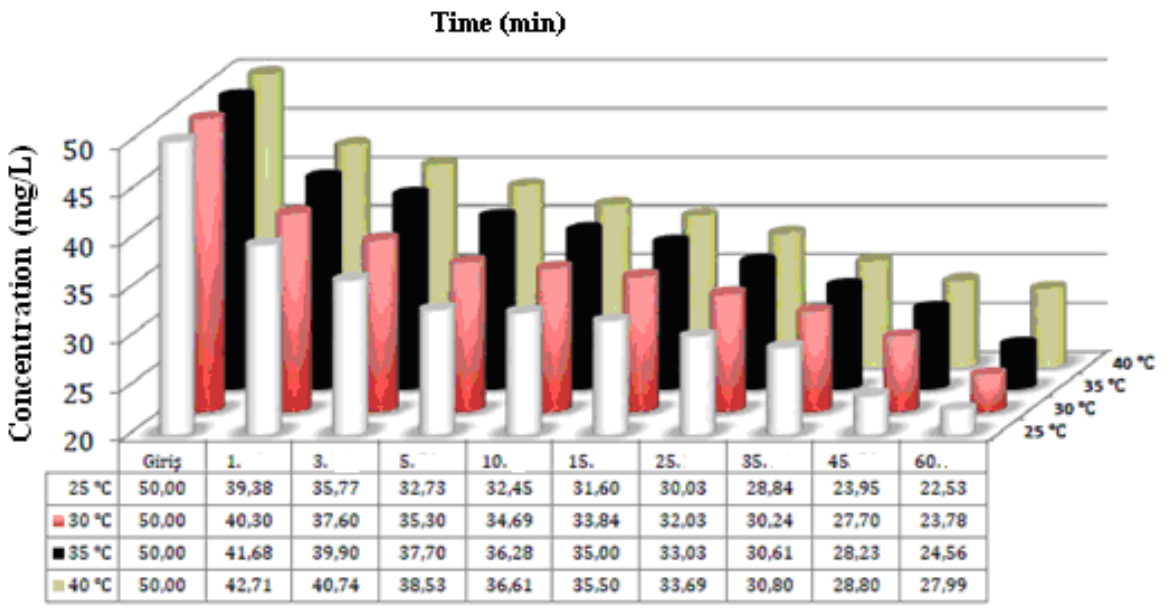

Figure 5. Temperature effect on the adsorption at $50 \mathrm{mg} / \mathrm{L}$ concentration

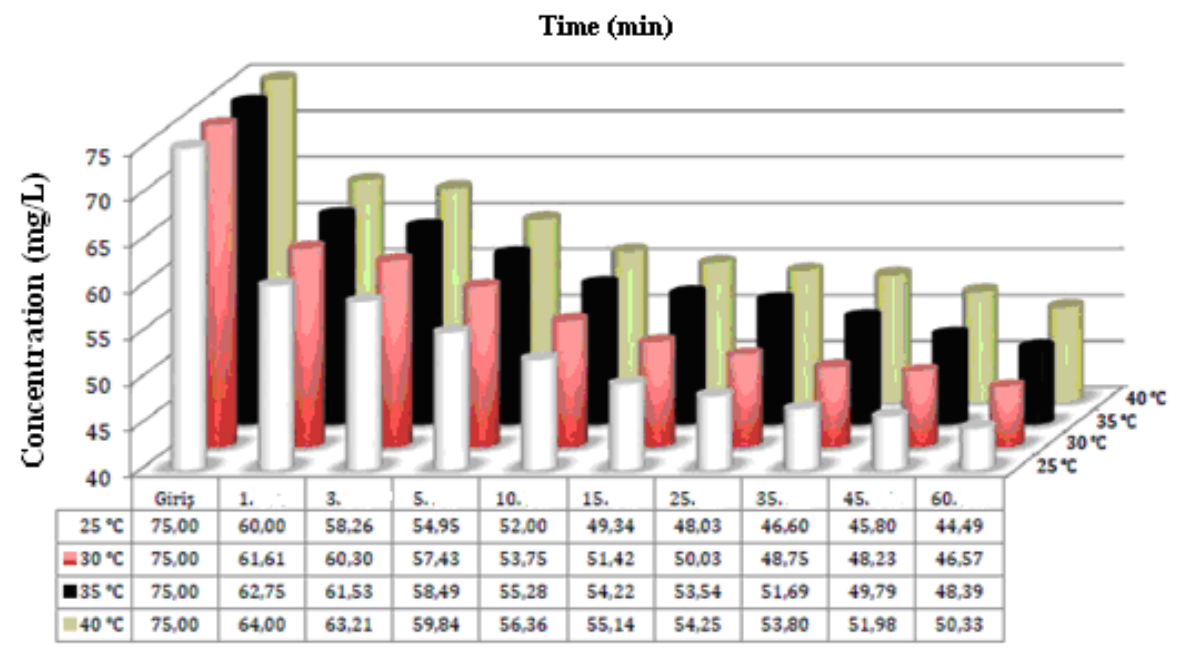

Figure 6. Temperature effect on the adsorption at $75 \mathrm{mg} / \mathrm{L}$ concentration 


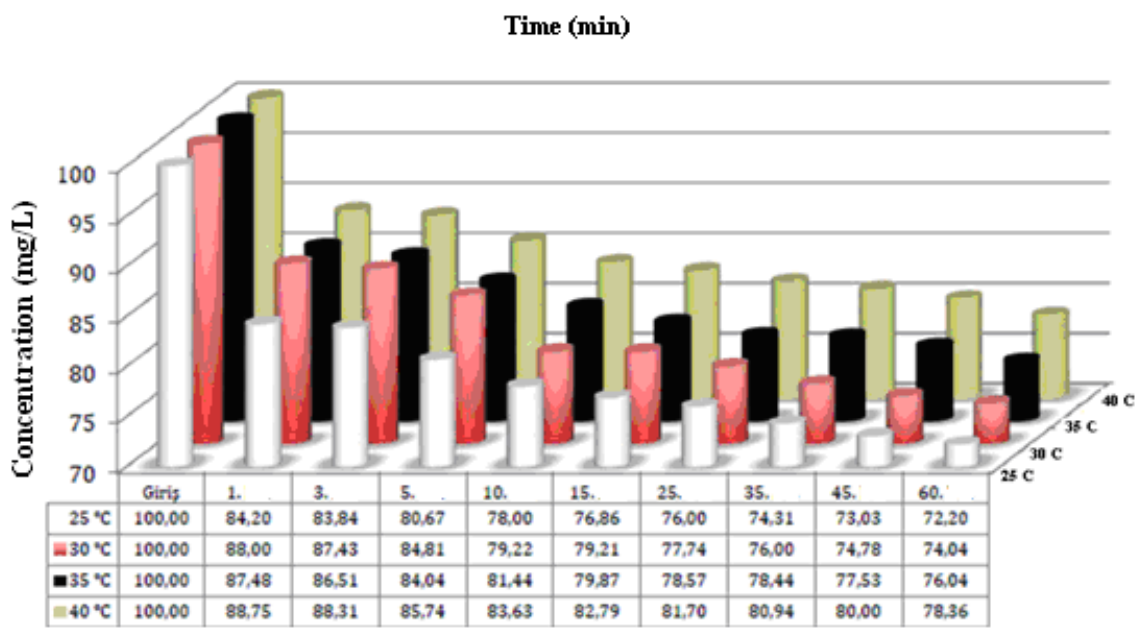

Figure 7. Temperature effect on the adsorption at100 $\mathrm{mg} / \mathrm{L}$ concentration

Ho et al. described a kinetic process of the adsorption of divalent metal ions onto peat, in which the chemical bonding among divalent metal ions and polar functional groups on peat, such as aldehydes, ketones, acids, and phenolics are responsible for the cation-exchange capacity of the peat (Ho and McKay, 1998). The linear form of the pseudo-second-order kinetic model is given as follows (Ho and McKay, 1998).

$$
\frac{t}{q_{t}}=\frac{1}{k_{2} \cdot q_{e}^{2}}+\frac{t}{q_{e}}
$$

Where $k_{1}$ is the rate constant of the pseudo-first-order equation, $k_{2}$ is the rate constant of the pseudo-secondorder equation, $q_{\mathrm{e}}$ is the theoretically sorbed amount at equilibrium, and $q_{\mathrm{t}}$ is the sorbed amount at any time $t$.

The feasibility of the pseudo-second-order and pseudofirst-order kinetic models can be examined by the regression analyses of the linearized equations. The analysis results are given in Table 1.

Table 1. Analysis results of the batch reactor kinetic models

\begin{tabular}{|c|c|c|c|c|c|c|c|}
\hline \multicolumn{2}{|c|}{ Concentration (mg/L) } & \multicolumn{3}{|c|}{ First Order Kinetic Model } & \multicolumn{3}{|c|}{ Second Order Kinetic Model } \\
\hline $25^{\circ} \mathrm{C}$ & $\begin{array}{l}\text { qe(exp.) } \\
\text { (mg/g) }\end{array}$ & $\begin{array}{c}k_{1} \\
\left(\min ^{-1}\right)\end{array}$ & $q_{e}(m g / g)$ & $\mathbf{R}^{2}$ & $\begin{array}{c}k_{2} \\
\text { (g/mg min) }\end{array}$ & $\mathrm{q}_{\mathrm{e}}(\mathrm{mg} / \mathrm{g})$ & $\mathbf{R}^{2}$ \\
\hline 25 & 1.58 & 0.0244 & 1.2165 & 0.8825 & 0.136 & 1.53 & 0.9697 \\
\hline 50 & 2.75 & 0.0415 & 1.6166 & 0.8198 & 0.071 & 2.78 & 0.9693 \\
\hline 75 & 3.05 & 0.0552 & 1.4246 & 0.9801 & 0.112 & 3.13 & 0.9978 \\
\hline 100 & 2.78 & 0.0559 & 1.2218 & 0.9653 & 0.135 & 2.84 & 0.9968 \\
\hline \multicolumn{8}{|c|}{$30^{\circ} \mathrm{C}$} \\
\hline 25 & 1.49 & 0.0492 & 1.2709 & 0.7334 & 0.125 & 1.45 & 0.9891 \\
\hline 50 & 2.62 & 0.0278 & 1.5156 & 0.9562 & 0.087 & 2.44 & 0.9623 \\
\hline 75 & 2.84 & 0.0518 & 1.3574 & 0.9635 & 0.111 & 2.91 & 0.9974 \\
\hline 100 & 2.60 & 0.0603 & 1.3819 & 0.9578 & 0.076 & 3.28 & 0.9966 \\
\hline \multicolumn{8}{|c|}{$35^{\circ} \mathrm{C}$} \\
\hline 25 & 1.44 & 0.0737 & 1.3639 & 0.9484 & 0.107 & 1.38 & 0.9990 \\
\hline 50 & 2.55 & 0.0392 & 1.6854 & 0.978 & 0.082 & 2.28 & 0.9592 \\
\hline 75 & 2.66 & 0.0468 & 1.3614 & 0.9508 & 0.084 & 2.71 & 0.9924 \\
\hline 100 & 2.40 & 0.0444 & 1.0051 & 0.9320 & 0.061 & 3.15 & 0.9965 \\
\hline \multicolumn{8}{|c|}{$40^{\circ} \mathrm{C}$} \\
\hline 25 & 1.36 & 0.0499 & 1.4148 & 0.9242 & 0.197 & 1.40 & 0.9953 \\
\hline 50 & 2.20 & 0.0578 & 1.6274 & 0.9374 & 0.087 & 2.08 & 0.9822 \\
\hline 75 & 2.46 & 0.0435 & 1.1891 & 0.923 & 0.078 & 255 & 0.9937 \\
\hline 100 & 2.16 & 0.0403 & 1.0592 & 0.9607 & 0.075 & 2.83 & 0.9944 \\
\hline
\end{tabular}

The correlation coefficient $R^{2}$ showed that the pseudosecond-order model fitted to the experimental data better than the pseudo-first order models. The coefficients of determination values for pseudo second order kinetic model were in the range of 0.95 and 0.99 . The rate constant of pseudo second order kinetic model decreased with the 
simultaneous increasing of concentration and temperature. The second-order rate constants listed (Table 1) have been used to estimate the activation energy of copper adsorption on walnut tree sawdust (Fil et al., 2012): The Activation energy of the adsorption process was calculated by using Arrhenius equation given as follows.

$$
\ln \left(k_{2}\right)=\ln \left(k_{0}\right)-\frac{E_{a}}{R_{g} \cdot T}
$$

Where, $E_{a}$ is activation energy $(\mathrm{kJ} / \mathrm{mol}), k_{2}$ is the rate constant of pseudo-second-order kinetic model (g/mol.min), $k_{0}$ is Arrhenius factor which is the temperature independent factor $(\mathrm{g} / \mathrm{mol}) . R_{g}$ is the gas constant $(\mathrm{J} / \mathrm{mol} . \mathrm{K})$ and $T$ is the solution temperature (K). The slope of plot of Ink $k_{2}$ versus $1 / T$ is used to evaluate $E_{a}$ which was found to be $15.79(\mathrm{~kJ} / \mathrm{mol})$ for copper adsorption.

\subsection{Effect of flow rate on copper removal in the fixed bed reactor}

The effect of solution flow rate on copper adsorption onto walnut tree sawdust was studies at $0.5,1.5,2.5 \mathrm{~mL} / \mathrm{min}$ flow rates and other parameters were kept as constant as follows: concentration $(100 \mathrm{mg} / \mathrm{L})$, bed height $(15 \mathrm{~cm})$, temperature $\left(25^{\circ} \mathrm{C}\right), \mathrm{pH}(5)$. The obtained results are given in Figure 8. As can be seen in Figure 8, the breakthrough time of copper removal increased with decreasing solution flow rate. The reason of this trend was the decreasing solution volume with decreasing solution flow rate and hence effective adsorbent surface increased against treated solution volume as volume-to-solid amount ratio increased.

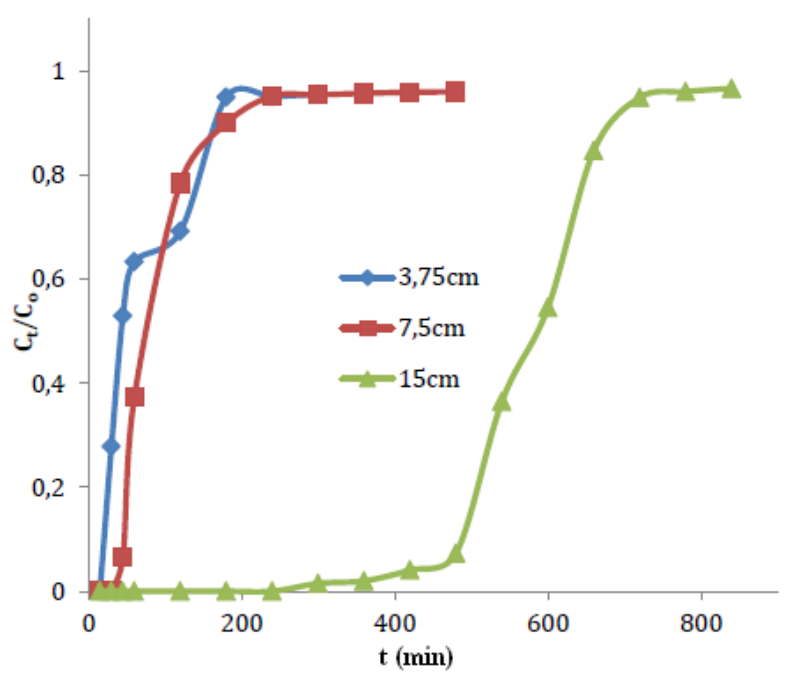

Figure 8. Bed height effect on the adsorption in the fixed bed

\subsection{Effect of concentration on copper removal in the fixed bed reactor}

The effect of concentration on copper adsorption onto walnut tree sawdust was studied at concentration range of 100 and $170 \mathrm{mg} / \mathrm{L}$. The other parameters kept constant were as follows: bed height $(15 \mathrm{~cm})$, flow rate $0.5 \mathrm{~mL} / \mathrm{min}$, temperature $\left(25^{\circ} \mathrm{C}\right), \mathrm{pH}$ (5). The results are shown in Figure 9.

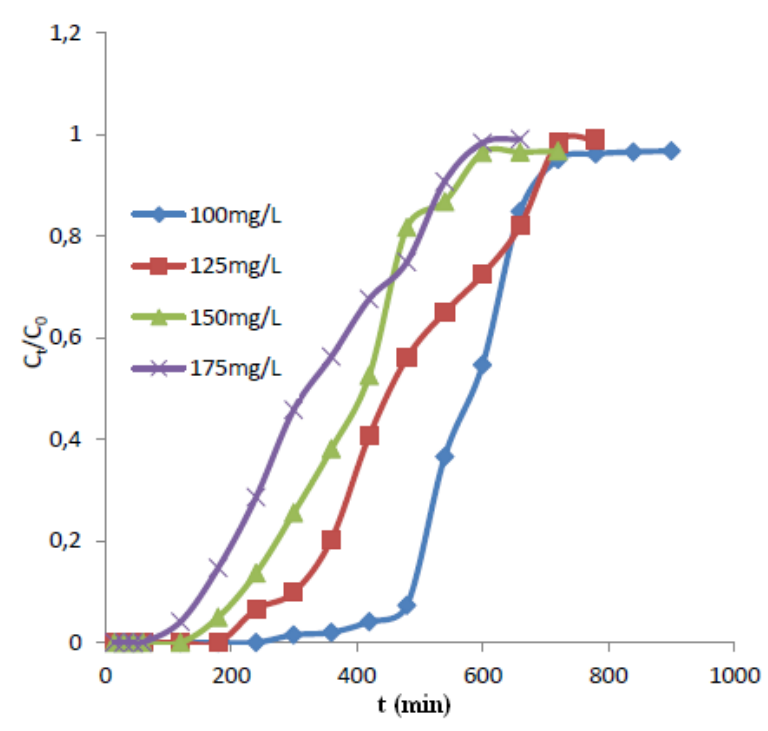

Figure 9. Concentration effect on the adsorption in the fixed bed

The breakthrough time increased with decreasing concentration as the effective adsorbent surface area increased against applied low copper concentration, i.e. as concentrations decreased, adsorbent-to-ion concentration ratio increases in the reactor.

\subsection{Effect of bed height on copper removal in the fixed bed reactor}

The effect of bed height (adsorbent amount) on copper adsorption onto walnut tree sawdust was studied at 3.75 , 7.5 and $15 \mathrm{~cm}$ bed height values.

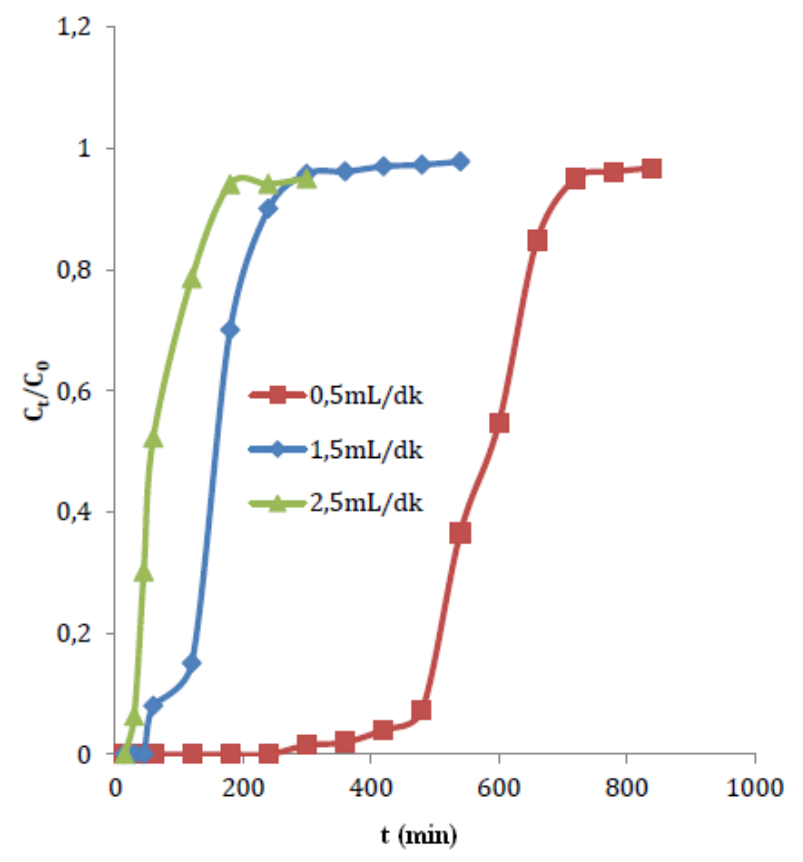

Figure 10. Flow rate effect on the adsorption in the fixed bed 
The other parameters were concentration $(100 \mathrm{mg} / \mathrm{L})$, solution flow rate $(0.5 \mathrm{~mL} / \mathrm{min})$, temperature $\left(25^{\circ} \mathrm{C}\right), \mathrm{pH}(5)$. The obtained results are given in Figure 10. It is shown in Figure 10 that the breakthrough time increased with increasing bed height. This was due to increasing effective adsorbent surface with increasing bed height against constant concentration.

\subsection{Fixed Bed Kinetics}

\subsubsection{Thomas Model}

The widely used kinetic models for pollutant removal from solutions in a fixed bed reactor are Thomas and YoonNelson models. The Thomas model describes the adsorbent rate for maximum and continuous adsorption (Rao et al., 2011).

$$
\ln \left(\frac{C_{0}}{C_{t}}-1\right)=\frac{k_{T H} \cdot q_{0} \cdot X}{Q}-\frac{k_{T H} \cdot C_{0}}{Q} \cdot V_{e f f}
$$

Where, $k_{T H}$ is Thomas rate constant ( $\mathrm{mL} / \mathrm{min} \mathrm{mg}$ ), $\mathrm{q}_{0}$ is the adsorption capacity of the bed, $V_{\text {eff }}$ is the treated solution volume $(\mathrm{mL}), X$ is the mass of the adsorbent $(\mathrm{g}), Q$ is the flow rate $(\mathrm{mL} / \mathrm{min})$. The main advantages of this model are its simplicity and reasonable accuracy in predicting the breakthrough curves under various operating conditions (Korkmaz et al., 2014).

\subsubsection{Yoon - Nelson Model}

The main logic of the Yoon-Nelson model is the presence of a linear ratio between pollutant leap from column and adsorbent consumption. The Yoon-Nelson model is not only less complicated than other models, but also requires no detailed data concerning the characteristics of the sorbate, the type of the sorbent, and the physical properties of the sorption bed (Korkmaz et al., 2014).

$$
\ln \left(\frac{C_{t}}{C_{0}-C_{t}}\right)=k_{Y N} \cdot t-\tau \cdot k_{Y N}
$$

Where, $\mathrm{C}_{0}$ is initial concentration $(\mathrm{mg} / \mathrm{L}), \mathrm{C}_{\mathrm{t}}$ is concentration at time $\mathrm{t}, k_{Y N}$ is the rate constant $\left(\mathrm{min}^{-1}\right), \tau$ is time for $50 \%$ breakthrough time, $t$ is time ( $\mathrm{min}$ ).

Kinetic analyses results for Yoon-Nelson and Thomas models are given in Table 2-3. The fixed bed reactor kinetics of copper removal by walnut tree sawdust fitted to the Thomas model. Coefficient of determination values were in the range of 0.87 and 0.98 for Thomas model. The experimentally calculated capacity values were in accordance with the capacity values predicted by the Thomas model. The rate constants obtained from the Thomas model increased with the increasing flow rate; however, decreased with the bed height and concentration.

\begin{tabular}{|c|c|c|c|c|c|}
\hline Parameters & Value & $\mathbf{R}^{\mathbf{2}}$ & $K_{\mathrm{YN}},\left(\mathrm{min}^{-1}\right)$ & $\mathrm{T},(\mathrm{min})$ & $\tau(\exp ),.(\min )$ \\
\hline \multirow{4}{*}{$\begin{array}{l}\text { Flow Rate } \\
\text { (mL/min) }\end{array}$} & 0.5 & 0.967 & 0.018 & 577.98 & 600 \\
\hline & 1.5 & 0.966 & 0.025 & 164.17 & 135 \\
\hline & 2.5 & 0.799 & 0.019 & 90.70 & 60 \\
\hline & 15 & 0.967 & 0.018 & 577.97 & 600 \\
\hline \multirow[t]{3}{*}{ Bed Height (cm) } & 7.5 & 0.958 & 0.019 & 71.73 & 90 \\
\hline & 3.75 & 0.874 & 0.019 & 43.40 & 45 \\
\hline & 100 & 0.967 & 0.018 & 577.98 & 600 \\
\hline \multirow{3}{*}{$\begin{array}{c}\text { Concentration } \\
(\mathrm{mg} / \mathrm{L})\end{array}$} & 125 & 0.956 & 0.013 & 339.82 & 420 \\
\hline & 150 & 0.986 & 0.014 & 385.95 & 350 \\
\hline & 175 & 0.935 & 0.012 & 474.62 & 240 \\
\hline \multicolumn{6}{|c|}{ Table 3. Analysis results of Thomas model } \\
\hline Parameter & Value & $\mathbf{R}^{2}$ & $\mathbf{k}_{\mathrm{TH}}$ & $q_{0}$ & $q_{\text {exp }}$ \\
\hline \multirow{4}{*}{$\begin{array}{l}\text { Flow Rate } \\
\text { (mL/min) }\end{array}$} & 0.5 & 0.983 & $1.9710-4$ & 5.78 & 5.90 \\
\hline & 1.5 & 0.966 & $2.5010-4$ & 4.93 & 5.50 \\
\hline & 2.5 & 0.874 & $4.8010-4$ & 2.57 & 4.40 \\
\hline & 15 & 0.983 & $1.9710-4$ & 5.78 & 5.95 \\
\hline \multirow[t]{3}{*}{ Bed Height $(\mathrm{cm})$} & 7.5 & 0.957 & $1.9210-4$ & 1.44 & 1.11 \\
\hline & 3.75 & 0.874 & $1.9110-4$ & 1.73 & 0.82 \\
\hline & 100 & 0.983 & $1.9710-4$ & 5.78 & 5.95 \\
\hline \multirow{3}{*}{$\begin{array}{l}\text { Concentration } \\
\text { (mg/L) }\end{array}$} & 125 & 0.936 & $9.7210-5$ & 5.90 & 5.83 \\
\hline & 150 & 0.979 & $9.2310-5$ & 5.78 & 6.08 \\
\hline & 175 & 0.940 & $6.9110-5$ & 5.81 & 6.24 \\
\hline
\end{tabular}

Table 2. Analysis results of Yoon-Nelson model

\section{Conclusion}

Copper removal from synthetic solutions was studied in the batch and fixed bed reactors. The obtained results can be summarized as follows. Optimum $\mathrm{pH}$ value was determined as 5 for copper removal from synthetic solutions. Copper removal efficiency increased with decreasing concentration and the process was more effective at 25 $\mathrm{mg} / \mathrm{L}$ concentration. Copper removal efficiency was high at higher adsorbent amounts. The copper removal was found as to be exothermic process and ideal solution temperature was $25^{\circ} \mathrm{C}$. The coefficient of determination value was 
calculated in the range of 0.95-0.99 for batch reactor. In fixed bed studies, copper removal efficiency increased at low flow rates, low concentrations and high bed heights. The copper removal kinetics could be described with the Thomas model and coefficients of determination values were in the range of 0.87-0.98. The Thomas model could approximately be predicted the experimental capacities. As a result, the raw walnut tree sawdust was found as effective adsorbent for copper removal from synthetic solutions.

\section{References}

Akça Y. and Polat A.A. (2007), Present Status and Future of Walnut Production in Turkey, The European Journal of Plant Science and Biotechnology, 1, 57-64.

Al-Homaidan A.A., Al-Houri H.J., Al-Hazzani A.A., Elgaaly G. and Moubayed N.M.S. (2014), Biosorption of copper ions from aqueous solutions by Spirulina platensis biomass, Arabian Journal of Chemistry, 7, 57-62.

Al-Rub F.A.A., El-Naas M.H., Ashour I. and Al-Marzouqi M. (2006), Biosorption of copper on Chlorella vulgaris from single, binary and ternary metal aqueous solutions, Process Biochemistry, 41, 457-464.

Bulut Y. and Tez Z, (2003), Removal of heavy metal ions by modified sawdust of walnut, Fresenius Environmental Bulletin, 12, 1499-1504.

Bulut Y. and Tez Z. (2007), Removal of heavy metals from aqueous solution by sawdust adsorption, Journal of Environmental Sciences, 19, 160-166.

Caprarescu S., Purcar V., Sârbu A., Radu A.-L., Ghiureab M. and Maiora I. (2014), The Use of Electrodıalysıs For Cu2+ Removal From Wastewater, Revue Roumaine De Chimie, 59, 639-644.

Cerjan-Stefanovic S., Grubisa D. and Smid V., (1996), Separation of copper, nickel, tin and lead by ion exchange from plating rinsewater, Plating and Surface Finishing, 83, 74-79.

Chabani M., Amrane A. and Bensmaili A. (2007), Kinetics of nitrates adsorption on Amberlite IRA 400 resin, Desalination, 206, 560-567.

Cojocaru C. and Zakrzewska-Trznadel G., (2007), Response surface modeling and optimization of copper removal from aqua solutions using polymer assisted ultrafiltration, Journal of Membrane Science, 298, 56-70.

Çakır E., (2015), Adsorption removal of $\mathrm{Cu}+2$ and $\mathrm{Cr}+6$ metals from synthetic waste water by using nut and mahogany shavings. Institute of Science and Technology, Ph.D. Thesis, Ataturk University, Erzurum.

Fil B.A., Boncukcuoglu R., Yilmaz A.E. and Bayar S. (2012), Adsorption Kinetics and Isotherms for the Removal of Zinc lons from Aqueous Solutions by an lon-Exchange Resin, Journal of the Chemical Society of Pakistan, 34, 841-848.

Fil B.A., Korkmaz M. and Özmetin C. (2014), An Empirical Model for Adsorption Thermodynamics of Copper (II) from Solutions onto illite Clay-Batch Process Design, Journal of the Chilean Chemical Society, 59, 2686-2691.

Ghazy S.E., Mahmoud I.A. and Ragab A.H. (2006), Removal of copper (II) from aqueous solutions by flotation using polyaluminum chloride silicate (PAX-XL60 S) as coagulant and carbonate ion as activator, Environmental Technology, 27, 53-61.
Han R., Li H., Li Y., Zhang J., Xiao H. and Shi J. (2006), Biosorption of copper and lead ions by waste beer yeast, Journal of Hazardous Materials, 137, 1569-1576.

Ho Y.S. and McKay G. (1998), Sorption of dye from aqueous solution by peat, Chemical Engineering Journal, 70, 115-124.

Juang R.-S. and Chen M.-N. (1997), Removal of Copper(II) Chelates of EDTA and NTA from Dilute Aqueous Solutions by Membrane Filtration, Industrial \& Engineering Chemistry Research, 36, 179-186.

Juang R.-S., Wu F.-C. and Tseng R.-L. (1999), Adsorption removal of copper(II) using chitosan from simulated rinse solutions containing chelating agents, Water Research, 33, 2403-2409.

Khormaei M., Nasernejad B., Edrisi M. and Eslamzadeh T., (2007), Copper biosorption from aqueous solutions by sour orange residue, Journal of Hazardous Materials, 149, 269-274.

Kitobo W., Gaydardzhiev S., Frenay J., Bastin D. and Ndala I., (2010), Separation of Copper and Zinc by Solvent Extraction During Reprocessing of Flotation Tailings, Separation Science and Technology, 45, 535-540.

Korkmaz M. (2011), Boron removal from boron containing waters using Purolite 108 resin. Institute of Science and Technology, Master Thesis, Balıkesir University, Balıkesir.

Korkmaz M., Fil B.A., Özmetin C. and Yaşar Y. (2014), Full factorial design of experiments for boron removal from Colemanite mine wastewater using Purolite S 108 resin, Bulgarian Chemical Communications, 46, 594-601.

Korkmaz M., Özmetin C., Fil B.A. and Yaşar Y. (2013), Determination of Parameters Affecting Copper Removal from Solutions by Clinoptilolite: Adsorption Isotherm and Thermodynamic, Iğdır University Journal of The Institute of Science and Technology, 3, 47-54.

Lagergren S. and Svenska B.K. (1898), About the theory of socalled adsorption of soluble substance, Kungliga Svenska Vetenskapsakademiens Handlingar, 24, 1-39.

Lu S. and Gibb S.W. (2008), Copper removal from wastewater using spent-grain as biosorbent, Bioresource Technology, 99, 1509-1517.

Luo C.-S. and Huang, S.-D. (1993), Removal of Copper from Aqueous Amminecopper(II) Solution by Foam Flotation, Separation Science and Technology, 28, 1395-1408.

Malamis S., Katsou E., Stylianou M., Haralambous K.J. and Loizidou M. (2010), Copper removal from sludge permeate with ultrafiltration membranes using zeolite, bentonite and vermiculite as adsorbents, Water Science and Technology, 61, 581-589.

Öğütveren Ü.B., Koparal S. and Özel E. (1997), Electrodialysis for the removal of copper ions from wastewater, Journal of Environmental Science and Health. Part A: Environmental Science and Engineering and Toxicology, 32, 749-761.

Özmetin C., Aydin Ö., Kocakerim M.M., Korkmaz M. and Özmetin E. (2009), An empirical kinetic model for calcium removal from calcium impurity-containing saturated boric acid solution by ion exchange technology using Amberlite IR-120 resin, Chemical Engineering Journal, 148, 420-424.

Preetha B. and Viruthagiri T. (2007), Application of response surface methodology for the biosorption of copper using Rhizopus arrhizus, Journal of Hazardous Materials, 143, 506-510.

Rao K.S., Anand S. and Venkateswarlu P. (2011), Modeling the kinetics of $\mathrm{Cd}(\mathrm{II})$ adsorption on Syzygium cumini L leaf powder 
in a fixed bed mini column, Journal of Industrial and Engineering Chemistry, 17, 174-181.

Sole K.C. and Hiskey J.B. (1995), Solvent extraction of copper by Cyanex 272, Cyanex 302 and Cyanex 301, Hydrometallurgy, 37, 129-147.

Veli S. and Pekey B., (2004), Removal of Copper from aqueous solution by ion Exchange resins, Fresenius Environmental Bulletin, 13, 244-250.

Vilar V.J.P., Botelho C.M.S. and Boaventura R.A.R. (2008), Copper removal by algae Gelidium, agar extraction algal waste and granulated algal waste: Kinetics and equilibrium, Bioresource Technology, 99, 750-762. 